\title{
DISPOSISI STATISTIS MAHASISWA DALAM PEMBELAJARAN STATISTIKA DASAR
}

\author{
Oleh: \\ Bambang Avip Priatna Martadiputra \\ Jurusan Pendidikan Matematika FPMIPA UPI \\ bambangavip@yahoo.com
}

\begin{abstract}
Tulisan ini berisi hasil penelitian tentang disposisi statistis mahasiswa S1 pendidikan matematika yang mengikuti perkuliahan Statistika Dasar pada sebuah Perguruan Tinggi Negeri di Kota Bandung. Disposisi statistis atau disposisi produktif terhadap statistika sebagai kecenderungan seseorang mahasiswa untuk berpikir dan berbuat dengan cara yang positif dan konstruktif yang berlangsung dalam kegiatan statistis. Hasil penelitian menginformasikan bahwa disposisi statistis mahasiswa pada awal semester, tangah semester, dan pada akhir semester masih belum optimal. Infromasi tersebut mengindikasikan bahwa model atau pendekatan pembelajaran statistika dasar yang digunakan oleh dosen kurang efektif untuk meningkatkan disposisi statistis mahasiswa.
\end{abstract}

Kata kunci: disposisi statistis

This paper contains the results of research on the disposition statistical for mathematics education students attending Basic Statistics at the State University in Bandung. The disposition statistical or productive disposition as a tendency of student to think and act in a positive and constructive in statistical activities. The results inform that the disposition statistical of student in the early of the semester, the hands of the semester, and at the end of the semester is not optimal. The information indicates that the model or approach of learning to basic statistics used of teacher is less effective to enhance of the student's disposition statistical.

Keywords: statistical disposition

\section{Pendahuluan}

Sasaran utama belajar statistika di perguruan tinggi bukan hanya memberi materi tetapi juga memberi keterampilan mahasiswa untuk belajar. Keterampilan belajar ini akan tercermin dalam bentuk disposisi produktif mahasiswa terhadap mata kuliah yang diikutinya. Berdasarkan pernyataan Kilpatrick, Swafford, \& Findell. (2001), Martadiputra (2012) mengartikan disposisi statistis atau disposisi produktif terhadap statistika sebagai kecenderungan seseorang mahasiswa untuk berpikir dan berbuat dengan cara yang positif dan konstruktif yang berlangsung dalam kegiatan statistis. 
Selanjutnya Martadiputra (2012) membagi disposisi statistis ke dalam tujuh dimensi, yaitu: 1) gairah dan perhatian serius dalam belajar; 2) rasa percaya diri; 3) fleksibilitias dalam mengeksplorasi ide dan alternatif pemecahan masalah; 4) kegigihan dalam menghadapi dan menyelesaikan masalah; 5) memonitor dan refeksi pemikiran; 6) rasa ingin tahu yang tinggi; dan 7) berbagi pendapat dengan orang lain.

Dimensi dan indikator dari disposisi statistis disajikan dalam bentuk Tabel 1 berikut.

Tabel 1

Dimensi dan Indikator Disposisi Statistis

\begin{tabular}{|c|c|c|}
\hline NO. & DIMENSI & INDIKATOR \\
\hline \multirow[t]{5}{*}{1.} & \multirow{5}{*}{$\begin{array}{l}\text { Gairah dan perhatian serius } \\
\text { dalam belajar. }\end{array}$} & 1. Minat terhadap perkuliahan statistika dasar. \\
\hline & & 2. Kehadiran tepat waktu dalam perkuliahan. \\
\hline & & $\begin{array}{l}\text { 3. Keinginan untuk mengerjakan dan } \\
\text { mengumpulkan tugas. }\end{array}$ \\
\hline & & 4. Keseriusan dalam mengikuti perkuliahan. \\
\hline & & 5. Keaktifan dalam mengikuti perkuliahan. \\
\hline \multirow[t]{5}{*}{2.} & \multirow[t]{5}{*}{ Rasa percaya diri. } & 1. Percaya diri dalam mengajukan pertanyaan. \\
\hline & & 2. Percaya diri dalam menjawab pertanyaan. \\
\hline & & $\begin{array}{l}\text { 3. Percaya diri dalam mengkomunikasikan } \\
\text { gagasan/ide. }\end{array}$ \\
\hline & & 4. Percaya diri dalam memecahkan masalah. \\
\hline & & 5. Percaya diri dalam menggunakan statistika. \\
\hline \multirow[t]{2}{*}{3.} & \multirow{2}{*}{$\begin{array}{l}\text { Fleksibilitas dalam } \\
\text { mengeksplorasi ide dan } \\
\text { alternatif pemecahan } \\
\text { masalah. }\end{array}$} & $\begin{array}{l}\text { 1. Fleksibilitas dalam mengeksplorasi ide-ide } \\
\text { statistis. }\end{array}$ \\
\hline & & $\begin{array}{l}\text { 2. Fleksibilitas dalam mencari alternatif } \\
\text { pemecahan masalah statistis. }\end{array}$ \\
\hline \multirow[t]{3}{*}{4.} & \multirow{3}{*}{$\begin{array}{l}\text { Kegigihan dalam } \\
\text { menghadapi dan } \\
\text { menyelesaikan masalah. }\end{array}$} & $\begin{array}{l}\text { 1. Kegigihan dalam menghadapi masalah } \\
\text { statistis. }\end{array}$ \\
\hline & & $\begin{array}{l}\text { 2. Kegigihan dalam menyelesaikan masalah } \\
\text { statistis. }\end{array}$ \\
\hline & & $\begin{array}{l}\text { 3. Kegigihan dalam memahami masalah, } \\
\text { prosedur, konsep, atau beberapa aspek penting } \\
\text { lainnya dari statistika dasar. }\end{array}$ \\
\hline \multirow[t]{2}{*}{5.} & \multirow[t]{2}{*}{$\begin{array}{l}\text { Memonitor dan } \\
\text { merefleksikan pemikiran. }\end{array}$} & $\begin{array}{l}\text { 1. Kemampuan mencermati ide-ide dan } \\
\text { pemikiran statistis yang dikemukakan dosen } \\
\text { dan atau mahasiswa. }\end{array}$ \\
\hline & & $\begin{array}{l}\text { 2. Keinginan untuk memberi tanggapan terhadap } \\
\text { ide dan pemikiran statistis orang lain } \\
\text { berdasarkan pemikiran sendiri. }\end{array}$ \\
\hline \multirow[t]{2}{*}{6.} & \multirow[t]{2}{*}{ Rasa ingin tahu yang tinggi. } & $\begin{array}{l}\text { 1. Keinginan menyelesaikan masalah-masalah } \\
\text { baru yang menantang. }\end{array}$ \\
\hline & & $\begin{array}{l}\text { 2. Keinginan mempelajari sendiri materi yang } \\
\text { akan dikuliahkan. }\end{array}$ \\
\hline
\end{tabular}




\begin{tabular}{|c|c|c|}
\hline NO. & DIMENSI & INDIKATOR \\
\hline & & $\begin{array}{l}\text { 3. Keinginan memiliki sumber bacaan lain selain } \\
\text { yang diwajibkan dosen. }\end{array}$ \\
\hline & & $\begin{array}{l}\text { 4. Keinginan mempelajari dan menanyakan hal- } \\
\text { hal nonrutin. }\end{array}$ \\
\hline \multirow[t]{2}{*}{7.} & \multirow[t]{2}{*}{$\begin{array}{l}\text { Berbagi pendapat dengan } \\
\text { orang lain. }\end{array}$} & $\begin{array}{l}\text { 1. Keinginan berbagi pendapat, ide, dan gagasan } \\
\text { dengan dosen. }\end{array}$ \\
\hline & & $\begin{array}{l}\text { 2. Keinginan berbagi pendapat, ide, dan gagasan } \\
\text { mahasiswa. }\end{array}$ \\
\hline
\end{tabular}

Oleh karena itu pendekatan pembelajaran yang lebih tepat digunakan di perguruan tinggi adalah andragogi. Menurut Knowles (1990), andragogi sebagai the art and science of helping adult learn. Dalam andragogi, mahasiswa diposisikan sebagai subjek aktif yang memiliki kemampuan untuk merencanakan arah, memilih bahan atau materi yang bermanfaat untuk dirinya, memikirkan cara terbaik untuk belajar, menganalisis dan menyimpulkan, serta mampu mengambil manfaat pendidikan sedangkan dosen berfungsi sebagai fasilitator (Nurhayati, E, 2011).

Berdasarkan uraian di atas muncul pertanyaan: bagaimana gambaran umum tentang disposisi statistis mahasiswa S1 pendidikan matematika yang sedang mengikuti pembelajaran statistika dasar?

\section{Pembahasan}

Pada bagian ini akan diuraikan hasil penelitian yang telah penulis lakukan tentang disposisi statistis mahasiswa S1 pendidikan matematika yang sedang mengikuti pembelajaran statistika dasar pada sebuah Perguruan Tinggi Negeri di kota Bandung dengan menggunakan metode kuasi-eksperimen. Disposisi statistis mahasiswa diukur dengan menggunakan skala disposisi statistis berbentuk skala Likert yang dilakukan pada awal semester (DS_awal), tengah semester (DS_tengah), dan akhir semester (DS_akhir). Dalam penelitian tersebut, kemampuan statistis awal mahasiswa dikelompokkan menjadi tiga, yaitu: tinggi, sedang, dan rendah.

Secara umum, rata-rata dan standar deviasi untuk disposisi statistis awal mahasiswa pada semester (DS_awal), disposisi statistis pada tengah semester (DS_tengah), dan disposisi statistis pada akhir semester (DS_akhir) untuk kelompok rendah, kelompok sedang, dan kelompok tinggi disajikan dalam bentuk Tabel Winner seperti terlihat pada Tabel 2 pada halaman selanjutnya. 
Tabel 2

Tabel Winner untuk Disposisi Statistis Mahasiswa Pada Awal, Tengah, dan Akhir Semester

\begin{tabular}{|l|c|c|c|c|c|c|}
\hline \multirow{3}{*}{ kelompok } & \multicolumn{6}{|c|}{ DISPOSISI STATISTIS (DS) } \\
\cline { 2 - 7 } & \multicolumn{2}{|c|}{ DS_Awal } & \multicolumn{2}{c|}{ DS_Tengah } & \multicolumn{2}{c|}{ DS_Akhir } \\
\cline { 2 - 7 } & Mean & Std. Dev & Mean & Std.Dev & Mean & Std. Dev \\
\hline Rendah & 65,84 & 13,96 & 62,86 & 11,33 & 62,73 & 11,71 \\
\hline Sedang & 65,51 & 8,72 & 64,31 & 7,66 & 67,03 & 9,53 \\
\hline Tinggi & 66,52 & 8,97 & 67,83 & 7,49 & 69,89 & 9,49 \\
\hline Total & 65,77 & 9,58 & 64,77 & 8,30 & 66,85 & 9,92 \\
\hline
\end{tabular}

Dari Tabel 2 terlihat bahwa secara umum disposisi statistis mahasiswa pada awal semester $(65,77)$, tengah semester $(64,77)$, dan akhir semester $(66,85)$ relatif tidak berbeda secara signifikan. Akan tetapi gain disposisi statistis mahasiswa dari awal sampai dengan tengah semester menunjukkan adanya penurunan sedangkan dari tengah sampai dengan akhir semester menunjukkan adanya peningkatan.

Pada awal semester, disposisi statistis mahasiswa kelompok tinggi, sedang, dan rendah relatf tidak berbeda secara signifikan. Pada tengah semester terlihat ada perbedaan disposisi statistis yang sangat signifikan antara mahasiswa kelompok tinggi, sedang, dan rendah. Disposisi statistis mahasiswa kelompok tinggi relatif lebih tinggi dari mahasiswa kelompok sedang, dan disposisi statistis mahasiswa kelompok sedang relatif lebih tinggi daripada mahasiswa kelompok rendah. Pada akhir semester, disposisi statistis mahasiswa kelompok tinggi masih tetap relatif lebih tinggi daripada mahasiswa kelompok sedang, dan disposisi statistis mahasiswa kelompok sedang relatif lebih tinggi daripada mahasiswa kelompok rendah.

Tabel Winner untuk peningkatan disposisi statistis mahasiswa disajikan dalam Tabel 3 berikut.

Tabel 3

Tabel Winner untuk Gain Disposisi Statistis Mahasiswa pada Periode 1 dan Periode 2

\begin{tabular}{|l|c|c|c|c|}
\hline \multirow{3}{*}{ Kelompok } & \multicolumn{3}{|c|}{ GAIN DISPOSISI STATISTIS } \\
\cline { 2 - 5 } & $\begin{array}{c}\text { Periode 1 } \\
\text { (awal-tengah semester) }\end{array}$ & \multicolumn{2}{c|}{$\begin{array}{c}\text { Periode 2 } \\
\text { (tengah-akhir semester) }\end{array}$} \\
\cline { 2 - 5 } & Mean & Std. Dev & Mean & Std. Dev \\
\hline Rendah & $-0,1342$ & 0,1766 & $-0,0036$ & 0,0939 \\
\hline Sedang & $-0,0788$ & 0,2913 & 0,0819 & 0,1629 \\
\hline Tinggi & $-0,0161$ & 0,3274 & 0,0726 & 0,1425 \\
\hline Total & $-0,0759$ & 0,2783 & 0,0646 & 0,1491 \\
\hline
\end{tabular}

Dari Tabel 3 terlihat bahwa secara umum gain disposisi statistis mahasiswa pada periode 1 (awal-tengah semester) menunjukkan penurun sebesar -0,0759. Gain 
disposisi statistis mahasiswa kelompok tinggi, sedang, dan rendah pada periode 1 menunjukkan adanya penurunan. Sedangkan pada periode 2 (tengah-akhir semester) gain disposisi statistis mahasiswa menunjukkan adanya peningkatan sebesar 0,0646 . Gain disposisi statistis mahasiswa kelompok tinggi dan sedang menunjukan adanya peningkatan, sedangkan untuk kelompok rendah menunjukkan adanya penurunan.

Deskripsi lebih rinci tentang besarnya peningkatan atau penurunan disposisi statistis untuk mahasiswa pada periode 1 dan periode 2 disajikan dalam Tabel 4 berikut.

\section{Tabel 4 \\ Peningkatan Disposisi Statistis Mahasiswa pada Periode 1 dan Periode 2 untuk Setiap Dimensi dan Indikator}

\begin{tabular}{|c|c|c|c|c|}
\hline Dimensi dan Indikator Disposisi Statistis & \multicolumn{2}{|c|}{ Periode 1} & \multicolumn{2}{|c|}{ Periode 2} \\
\hline A. Gairah dan perhatian serius dalam belajar & Gain & Ket & Gain & Ket \\
\hline 1) Minat terhadap perkuliahan statistika dasar & $-0,33$ & Turun & 0,11 & Naik \\
\hline 2) Kehadiran tepat waktu dalam perkuliahan & $-0,09$ & Turun & $-0,03$ & Turun \\
\hline $\begin{array}{l}\text { 3) Keinginan untuk mengerjakan dan } \\
\text { mengumpulkan tugas }\end{array}$ & $-0,13$ & Turun & 0,08 & Naik \\
\hline 4) Keseriusan dalam mengikuti perkuliahan & $-0,24$ & Turun & 0,01 & Naik \\
\hline 5) Keaktifan dalam mengikuti perkuliahan & $-0,11$ & Turun & 0,06 & Naik \\
\hline \multicolumn{5}{|l|}{ B. Rasa percaya diri } \\
\hline 1) Percaya diri dalam mengajukan pertanyaan & $-0,05$ & Turun & 0,06 & Naik \\
\hline 2) Percaya diri dalam menjawab pertanyaan & $-0,10$ & Turun & 0,01 & Naik \\
\hline $\begin{array}{l}\text { 3) Percaya diri dalam mengkomunikasikan } \\
\text { gagasan/ide }\end{array}$ & $-0,05$ & Turun & 0,02 & Naik \\
\hline 4) Percaya diri dalam memecahkan masalah & $-0,11$ & Turun & 0,05 & Naik \\
\hline 5) Percaya diri dalam menggunakan statistika & $-0,09$ & Turun & 0,01 & Naik \\
\hline \multicolumn{5}{|l|}{$\begin{array}{l}\text { C. Fleksibilitas dalam mengeksplorasi ide dan } \\
\text { alternatif pemecahan masalah }\end{array}$} \\
\hline $\begin{array}{l}\text { 1) Fleksibilitas dalam mengeksplorasi ide-ide } \\
\text { statistis }\end{array}$ & 0,02 & Naik & $-0,05$ & Turun \\
\hline $\begin{array}{l}\text { 2) Fleksibilitas dalam mencari alternatif } \\
\text { pemecahan masalah statistis }\end{array}$ & $-0,02$ & Turun & 0,01 & Naik \\
\hline \multicolumn{5}{|l|}{$\begin{array}{l}\text { D. Kegigihan dalam menghadapi dan } \\
\text { menyelesaikan masalah }\end{array}$} \\
\hline 1) Kegigihan dalam menghadapi masalah statistis & $-0,04$ & Turun & 0,02 & Naik \\
\hline 2) Kegigihan dalam menyelesaikan masalah & $-0,09$ & Turun & 0,04 & Naik \\
\hline
\end{tabular}




\begin{tabular}{|c|c|c|c|c|}
\hline Dimensi dan Indikator Disposisi Statistis & \multicolumn{2}{|c|}{ Periode 1} & \multicolumn{2}{|c|}{ Periode 2} \\
\hline \multicolumn{5}{|l|}{ statistis } \\
\hline $\begin{array}{l}\text { 3) Kegigihan dalam memahami masalah, prosedur, } \\
\text { konsep, atau beberapa aspek penting lainnya } \\
\text { dari statistika dasar }\end{array}$ & $-0,09$ & Turun & 0,00 & Tetap \\
\hline \multicolumn{5}{|l|}{ E. Memonitor dan merefleksikan pemikiran } \\
\hline $\begin{array}{l}\text { 1) Kemampuan mencermati ide-ide dan pemikiran } \\
\text { statistis yang dikemukakan dosen dan atau } \\
\text { mahasiswa }\end{array}$ & $-0,16$ & Turun & 0,05 & Naik \\
\hline $\begin{array}{l}\text { 2) Keinginan untuk memberi tanggapan terhadap } \\
\text { ide dan pemikiran statistis orang lain } \\
\text { berdasarkan pemikiran sendiri }\end{array}$ & $-0,16$ & Turun & 0,15 & Naik \\
\hline \multicolumn{5}{|l|}{ F. Rasa ingin tahu yang tinggi } \\
\hline $\begin{array}{l}\text { 1) Keinginan menyelesaikan masalah-masalah } \\
\text { baru yang menantang }\end{array}$ & $-0,03$ & Turun & $-0,04$ & Turun \\
\hline $\begin{array}{l}\text { 2) Keinginan mempelajari sendiri materi yang } \\
\text { akan dikuliahkan }\end{array}$ & $-0,19$ & Turun & 0,24 & Naik \\
\hline $\begin{array}{l}\text { 3) Keinginan memiliki sumber bacaan lain selain } \\
\text { yang diwajibkan dosen }\end{array}$ & 0,01 & Naik & $-0,02$ & Turun \\
\hline $\begin{array}{l}\text { 4) Keinginan mempelajari dan menanyakan hal- } \\
\text { hal nonrutin }\end{array}$ & $-0,07$ & Turun & 0,03 & Naik \\
\hline \multicolumn{5}{|l|}{ G. Berbagi pendapat dengan orang lain } \\
\hline $\begin{array}{l}\text { 1) Keinginan berbagi pendapat, ide, dan gagasan } \\
\text { dengan dosen }\end{array}$ & 0,03 & Naik & 0,07 & Naik \\
\hline \multirow[t]{3}{*}{$\begin{array}{l}\text { 2) Keinginan berbagi pendapat, ide, dan gagasan } \\
\text { mahasiswa }\end{array}$} & $-0,05$ & Turun & 0,05 & Naik \\
\hline & $-0,092$ & Mean & 0,040 & Mean \\
\hline & 0,083 & Stdev & 0,064 & Stdev \\
\hline
\end{tabular}

Dari Tabel 4 terlihat bahwa:

1. Setelah mengikuti perkuliahan statistika dasar selama periode 2 ternyata peningkatan disposisi statistis mahasiswa menunjukan penurunan sebesar -0,092 (rendah) walaupun penurunannya tidak signifikan.

2. Dari 23 indikator disposisi statistis, ternyata:

a. $20(86,96,17 \%)$ indikator mengalami penurunan, yaitu: 1) Minat terhadap perkuliahan statistika dasar; 2) Kehadiran tepat waktu dalam perkuliahan; 3) Keinginan untuk mengerjakan dan mengumpulkan tugas; 4) Keseriusan dalam mengikuti perkuliahan; 5) Keaktifan dalam mengikuti perkuliahan; 6) Percaya diri dalam mengajukan pertanyaan; 7) Percaya diri dalam menjawab pertanyaan; 8) Percaya diri dalam mengkomunikasikan gagasan/ide; 9) Percaya diri dalam memecahkan masalah; 10) Percaya diri dalam menggunakan statistika; 11) Fleksibilitas dalam mencari alternatif 
pemecahan masalah statistis; 12) Kegigihan dalam menghadapi masalah statistis: 13) Kegigihan dalam menyelesaikan masalah statistis; 14) Kegigihan dalam memahami masalah, prosedur, konsep, atau beberapa aspek penting lainnya dari statistika dasar; 15) Kemampuan mencermati ide-ide dan pemikiran statistis yang dikemukakan dosen dan atau mahasiswa; 16. Keinginan untuk memberi tanggapan terhadap ide dan pemikiran statistis orang lain berdasarkan pemikiran sendiri; 17) Keinginan menyelesaikan masalah-masalah baru yang menantang; 18) Keinginan mempelajari sendiri materi yang akan dikuliahkan; 19) Keinginan mempelajari dan menanyakan hal-hal nonrutin; dan 20) Keinginan berbagi pendapat, ide, dan gagasan mahasiswa.

b. $3(13,04 \%)$ indikator mengalami peningkatan, yaitu: 1) Fleksibilitas dalam mengeksplorasi ide-ide statistis; 2) Keinginan memiliki sumber bacaan lain selain yang diwajibkan dosen; dan 3) Keinginan berbagi pendapat, ide, dan gagasan dengan dosen.

3. Untuk dimensi gairah dan perhatian serius dalam belajar, seluruh (5 indikator) mengalami penurunan. Untuk dimensi rasa percaya diri, seluruh (5 indikator) mengalami penurunan. Untuk dimensi fleksibilitas dalam mengeksplorasi ide dan alternatif pemecahan masalah, 1 indikator mengalami penurunan dan 1 indikator mengalami peningkatan. Untuk dimensi kegigihan dalam menghadapi dan menyelesaikan masalah, seluruh (3 indikator) mengalami peningkatan. Untuk dimensi memonitor dan merefleksikan pemikiran, seluruh (2 indikator) mengalami penurunan. Untuk dimensi rasa ingin tahu yang tinggi, 1 indikator mengalami peningkatan, dan 3 indikator mengalami penurunan. Untuk dimensi berbagi pendapat dengan orang lain, 1 indikator mengalami peningkatan dan 1 indikator mengalami penurunan.

Dari Tabel 4 terlihat juga bahwa:

1. Setelah mengikuti perkuliahan statistika dasar selama periode 2 ternyata peningkatan disposisi statistis mahasiswa reguler yang menggunakan pembelajaran konvensional menunjukan peningkatan walaupun tidak signifikan yaitu sebesar 0,040 (rendah).

2. Dari 23 indikator disposisi statistis, ternyata:

a. $4(17,39 \%)$ indikator yang mengalami penurunan, yaitu: 1) Kehadiran tepat waktu dalam perkuliahan; 2) Fleksibilitas dalam mengeksplorasi ide-ide statistis; 3) Keinginan menyelesaikan masalah-masalah baru yang menantang; dan 4) Keinginan memiliki sumber bacaan lain selain yang diwajibkan dosen.

b. $1(4,35 \%)$ indikator yang tidak mengalami perubahan, yaitu kegigihan dalam memahami masalah, prosedur, konsep, atau beberapa aspek penting lainnya dari statistika dasar. 
c. $18(78,26 \%)$ indikator mengalami peningkatan, yaitu: 1) Minat terhadap perkuliahan statistika dasar; 2) Keinginan untuk mengerjakan dan mengumpulkan tugas; 3) Keseriusan dalam mengikuti perkuliahan; 4) Keaktifan dalam mengikuti perkuliahan; 5) Percaya diri dalam mengajukan pertanyaan; 6) Percaya diri dalam menjawab pertanyaan; 7) Percaya diri dalam mengkomunikasikan gagasan/ide; 8) Percaya diri dalam memecahkan masalah; 9) Percaya diri dalam menggunakan statistika; 10) Fleksibilitas dalam mencari alternatif pemecahan masalah statistis; 11) Kegigihan dalam menghadapi masalah statistis; 12) Kegigihan dalam menyelesaikan masalah statistis; 13) Kemampuan mencermati ide-ide dan pemikiran statistis yang dikemukakan dosen dan atau mahasiswa; 14) Keinginan untuk memberi tanggapan terhadap ide dan pemikiran statistis orang lain berdasarkan pemikiran sendiri; 15) Keinginan mempelajari sendiri materi yang akan dikuliahkan; 16) Keinginan mempelajari dan menanyakan hal-hal nonrutin; 17) Keinginan berbagi pendapat, ide, dan gagasan dengan dosen; dan 18) Keinginan berbagi pendapat, ide, dan gagasan mahasiswa.

3. Untuk dimensi gairah dan perhatian serius dalam belajar, 4 indikator mengalami peningkatan, dan 1 indikator mengalami penurunan. Untuk dimensi rasa percaya diri, seluruh (5 indikator) mengalami peningkatan. Untuk dimensi fleksibilitas dalam mengeksplorasi ide dan alternatif pemecahan masalah, 1 indikator mengalami peningkatan dan 1 indikator mengalami penurunan. Untuk dimensi kegigihan dalam menghadapi dan menyelesaikan masalah, 2 indikator mengalami peningkatan dan 1 indikator tidak mengalami peningkatan maupun penurunan. Untuk dimensi memonitor dan merefleksikan pemikiran, seluruh (2 indikator) mengalami peningkatan. Untuk dimensi rasa ingin tahu yang tinggi, 2 indikator mengalami peningkatan, dan 2 indikator tidak mengalami penurunan dan peningkatan. Untuk dimensi berbagi pendapat dengan orang lain, seluruh (2 indikator) mengalami peningkatan

Deskripsi tentang peningkatan indikator disposisi statistis mahasiswa yang menggunakan pembelajaran konvensional pada periode 1 dan periode 2 disajikan dalam Diagram 1 berikut. 


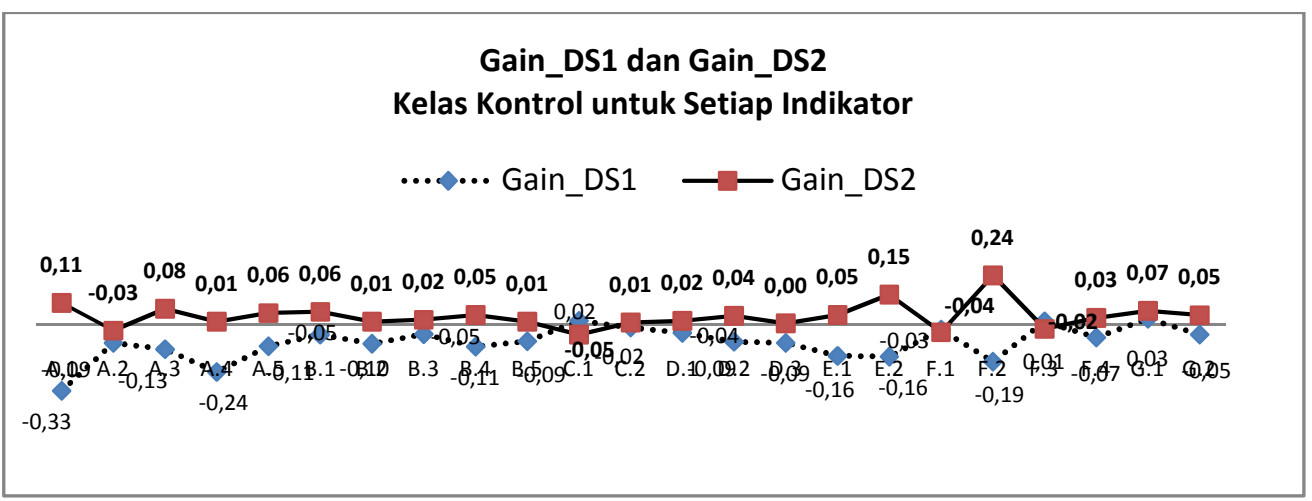

\section{Diagram 1}

\section{Penutup}

Dari pembahasan terlihat bahwa secara umum disposisi statistis mahasiswa S1 pendidikan matematika pada sebuah PTN di kota Bandung yang sedang mengikuti pembelaran statistika dasar masih belum optimal baik pada awal semester, tengah semester, maupun pada akhir semester. Ini mengindikasikan bahwa model atau pendekatan pembelajaran yang selama ini digunakan oleh dosen kurang efektif untuk meningkatkan disposisi statistis mahasiswa. Artinya dosen dituntut untuk dapat memilih dan atau menemukan model atau pendekatan pembelajaran yang dapat mengoptimalkan disposisi statistis mahasiswa. Salah satu model pembelajaran yang dapat meningkatkan disposisi statistis mahasiswa adalah MEAs yang dimodifikasi yang telah dikembangkan oleh Martadiputra (2012).

\section{DAFTAR PUSTAKA}

Knowles, M,S, (1980). The Modern Practice af Adult Education From Pedagogy to Andragogy. New York: The Adult Education Company.

Kilpatrick, J., Swafford, J., dan Findell, B. (2001). Adding It Up: Helping Chldren Learn Mathematics. Washington, DC: National Academy Press.

Martadiputra, BAP. (2012). Meningkatkan Kemampuan Berpikir Statistis Mahasiswa S1 Pendidikan Matematika Melalui Pembelajaran MEAs yang Dimodifikasi. Bandung: SPs UPI (Disertasi).

Nurhayati, E. (2011). Psikologi Pendidikan Inovatif. Yogyakarta: Pustaka Pelajar. 